\title{
Factors Influencing Liana Species Richness and Structure following Anthropogenic Disturbance in a Tropical Forest, Ghana
}

\author{
Patrick Addo-Fordjour, Philip El Duah, and David Kafui Kudjo Agbesi \\ Department of Theoretical and Applied Biology, Kwame Nkrumah University of Science and Technology, Kumasi, Ghana \\ Correspondence should be addressed to Patrick Addo-Fordjour; paddykay77@yahoo.com
}

Received 13 November 2012; Accepted 29 November 2012

Academic Editors: D. Huber, Z. Kaya, T. L. Noland, and B. Schirone

Copyright (C) 2013 Patrick Addo-Fordjour et al. This is an open access article distributed under the Creative Commons Attribution License, which permits unrestricted use, distribution, and reproduction in any medium, provided the original work is properly cited.

\begin{abstract}
The study was conducted to determine the factors that influenced liana species richness and structure in forests of different disturbance intensities (high, moderate, and low disturbance forests) in the Southern Scarp Forest Reserve, Ghana. Within each forest, lianas $\left(\mathrm{dbh} \geq 2 \mathrm{~cm}\right.$ ) were enumerated in six $25 \times 20 \mathrm{~m}^{2}$ plots located along transects. Soil physicochemical properties and forest structure were determined within the plots. Liana species richness and abundance were significantly lower in the high disturbance forest $(P<0.001)$ whereas basal area was significantly higher in the low disturbance forest $(P=0.014)$. Tree abundance and dbh significantly predicted liana species richness and structure in the study $(P<0.05)$. On the basis of the importance value index, three main liana communities, each corresponding with a forest type, were identified. Stepwise multiple regression analysis revealed that exchangeable magnesium and calcium, and total exchangeable bases were the main soil variables that affected liana species richness. Liana structure was influenced by the above-mentioned soil variables as well as exchangeable potassium and sodium, and $\mathrm{pH}$. The present study has demonstrated that changes in liana species richness and structure following human disturbance may be due to variations in soil properties and forest structure.
\end{abstract}

\section{Introduction}

Lianas are woody climbers that are rooted in the soil and climb other plants to the reach forest canopy [1]. They have significant influence on forest ecology and ecosystem function, particularly in tropical forests (cf. [2]). For instance, they help to stabilise the microclimate of the forest floor by forming a mass of leafy vegetation to close canopy gaps [3]. Lianas may help maintain tree diversity in the forest by causing tree falls which could reduce the dominance of tree species [4]. Heavy liana loads on trees can cause mechanical damage of the hosts and also reduce their growth rates $[5,6]$. Additionally, lianas could impact negatively on natural regeneration of trees in forest ecosystems [7]. In the light of recent reports of increasing liana abundance in tropical forests [8-14], lianas could modify forest ecosystems through their influence on tree regeneration and growth. Understanding the factors that govern liana community assembly in tropical forests is therefore of utmost priority, and necessary in developing forest conservation strategies.
Human disturbance has been identified as one of the main drivers of liana success in tropical forest ecosystems $[3,4,11,15,16]$. Both patterns of increasing and decreasing liana diversity and structure have been reported in tropical forests, although majority of them have centered on the former [17]. Though human disturbance could have direct effects on liana communities through species removal, it could also cause changes in certain characteristics of the ecosystem such as forest structure and soil properties, which in turn, could influence liana community assembly. For this reason, the indirect effects of human disturbance on liana success following disturbance should be factored in studies that attempt to examine the role of human disturbance in structuring liana communities. Currently, studies that look at the indirect effects of human disturbance on liana success, mediated by changes in forest structure and soil properties, are scarce. Though a number of studies have considered the effects of environmental factors such as total rainfall, seasonality of rainfall, altitude and soil properties on lianas $[2,3,18]$, they were not related to human disturbance. 

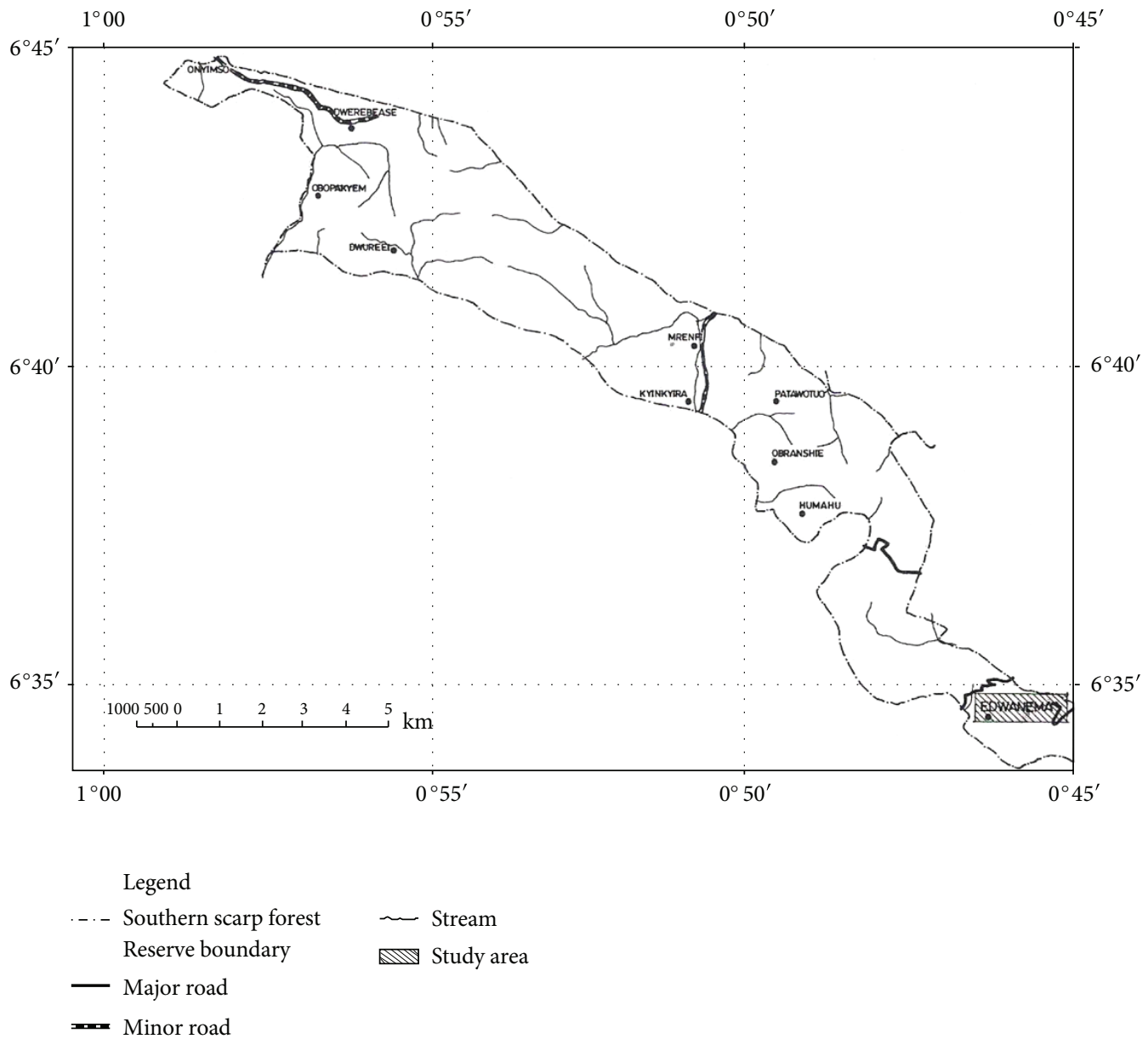

FIGURE 1: A section of the Southern Scarp Forest Reserve showing the study site.

Consequently, information on the factors influencing liana species richness and structure following human disturbance is scanty. The current study was, therefore, conducted to determine the factors that affect liana species richness and structure within forests modified by human disturbance in the Southern Scarp Forest Reserve, Ghana.

\section{Materials and Methods}

2.1. Study Area. This study was conducted in the Southern Scarp Forest Reserve (coordinates, latitude $6.55^{\circ}$ and longitude $-0.66667^{\circ}$ ) located about $14.71 \mathrm{~km}$ to the North-West of Mpraeso near Osubeng, in the Eastern Region of Ghana (Figure 1). The reserve covers an estimated area of about 15,462 hectares. It is the largest forest reserve in the Eastern Region of Ghana and falls within the moist semideciduous forest zone.

The reserve experiences double maxima rainfall pattern since it falls within the west semiequatorial region. The major rainy season starts from April and ends in July whereas the minor rainy season starts from September and ends in October. The forest experiences an annual average rainfall between $1580 \mathrm{~mm}$ and $1780 \mathrm{~mm}$, with mean monthly temperature ranging from as high as $30^{\circ} \mathrm{C}$ in the dry season to about $26^{\circ} \mathrm{C}$ in the wet season. Relative humidity ranges between $75 \%$ and $80 \%$.

2.2. Plot Selection and Demarcation. The study was conducted in three forest types with varying disturbance index/intensity (DI): low disturbance forest (DI $=0.07)$, moderate disturbance forest $(\mathrm{DI}=0.14)$, and high disturbance forest ( $\mathrm{DI}=0.28)$. Disturbance index (intensity) was determined for each forest as a percentage of trees that belonged to the pioneer species [19]. This index is similar to the "pioneer index" developed by Hawthorne [20, 21] and Hawthorne and Abu Juam [22] which has been shown to reflect disturbance history at various scales in Ghanaian forests [19]. Likewise, the disturbance index also incorporates the effects of all types of disturbance throughout recent history as indicated by Bongers et al. [19]. Differences in disturbance intensity reflected in differences in diversity and structure of the forest types. Farming and logging are the major human activities that have taken place in the forest. Two stands were sampled within each forest, and in each stand a transect of length $500 \mathrm{~m}$ was located. Three $25 \times$ $20 \mathrm{~m}^{2}$ plots were placed on alternate sides of each transect at 
a regular distance of $100 \mathrm{~m}$. Transect sampling was used in the study so as to include all the possible gradients of disturbance within each forest type.

2.3. Data Collection. Trees whose diameter at breast height (dbh) was $\geq 10 \mathrm{~cm}$ and lianas with $\mathrm{dbh} \geq 2 \mathrm{~cm}$ were identified, counted, and their dbh measured. Only lianas that were hosted on trees were included in the sampling. Trees were enumerated regardless of whether they were hosting lianas or not, so that liana infestation per plot could be determined, and the average for the forests calculated. Canopy cover was determined for the plots using a spherical densiometer. Plant identification was carried out by field observations with the assistance of a plant taxonomist as well as manuals and Floras [23-26]. Plant identification was later confirmed with herbarium specimens at the hebarium of Kwame Nkrumah University of Science and Technology, Kumasi, Ghana.

2.4. Collection and Analysis of Soil Samples. Using soil auger, soil samples were collected from the depth of $0-5 \mathrm{~cm}$, $5-15 \mathrm{~cm}$, and $15-25 \mathrm{~cm}$ within the $25 \times 20 \mathrm{~m}^{2}$ plots. There were five replicates for each depth in a plot. Soil samples collected were then composited to obtain a single sample per plot. Soil samples were analysed for $\mathrm{pH}\left(1: 1 \mathrm{H}_{2} \mathrm{O}\right)$, organic matter, total nitrogen, percent moisture, exchangeable calcium, exchangeable magnesium, exchangeable sodium, exchangeable potassium, exchangeable acidity $(\mathrm{Al}+\mathrm{H})$, available potassium, available phosphorous, total exchangeable bases (TEB), effective cation exchange capacity (ECEC), and percent base saturation at the Soil Research Institute of the Council for Scientific and Industrial Research, Kwadaso, Ghana, following the methods of Soil Survey Staff [27].

2.5. Statistical Analyses. Importance value index (IVI) of lianas was calculated using the following equation:

$$
\text { IVI = Relative density }
$$

+ Relative basal area + Relative frequency.

The patterns of liana species dominance were determined by conducting principal component analysis (PCA) on the IVI of the species.

To understand the effects of forest structure on liana species richness and structure, simple linear regression analysis was run between the following pairs of forest structure and liana variables: tree $\mathrm{dbh}$ versus liana $\mathrm{dbh}$, tree $\mathrm{dbh}$ versus liana abundance, tree abundance versus liana abundance, tree dbh versus liana basal area, canopy cover versus liana species richness, and canopy cover versus liana abundance. Liana species richness and abundance were compared between the forests with analysis of variance (ANOVA). The levels of the soil physicochemical properties were compared among the forests with ANOVA. Fisher's LSD pairwise comparison tests were used to determine differences of means among forest pairs.

Stepwise multiple regression analysis was conducted between liana species richness and structure (abundance, $\mathrm{dbh}$, and basal area), and soil variables to obtain the soil variables that explained variation in liana species richness and structure. The forward selection method was used to eliminate redundant soil variables and reduce collinearity. Pearson's correlation analysis was run to determine the relationships between liana infestation and the various soil properties as well as forest characteristics (tree abundance, tree basal area, and canopy cover). All analyses were performed with the 12th Edition of the GenStat software (VSN International Ltd., Hemel Hempstead, UK), except that the PCA which was conducted with the CANOCO software, at a significance level of $5 \%$.

\section{Results}

3.1. Liana Species Richness and Structure. In all, 57 liana species belonging to 35 genera and 19 families were identified in the study area (Table 1). Liana species richness was significantly lower in the high disturbance forest than the other forests. (Table $2 ; \mathrm{df}=2 ; P<0.001$ ). The most diverse families in the forest reserve were Apocynaceae ( 9 species), Fabaceae (7 species), and Celastraceae (7 species). The most speciesrich families in the low disturbance forest were Celastraceae, Apocynaceae, and Convolvulaceae which formed $43.5 \%$ of the total species in this forest type (Figure 2). The most species-rich families in the moderate disturbance forest were Apocynaceae, Celastraceae, Fabaceae, and Icacinaceae which contributed $56.0 \%$ of the species in this forest. In the high disturbance forest, Apocynaceae, Fabaceae, Connaraceae and Celastraceae constituted the most diverse families, contributing $60.0 \%$ of the species in this forest.

Altogether, there were 365 individuals of lianas identified within the Southern Scarp Forest Reserve, which translates into 406 individuals/ha. Liana abundance in the high disturbance forest was more than twice as high as that of the low disturbance forest and more than thrice as high as that of the moderate disturbance forest (Table 2). Liana abundance and infestation differed significantly between the forests (Table 2; $P<0.001)$. Mean liana dbh per plot was similar among the forests (Table 2; $P=0.149$ ). However, mean liana basal area per plot was significantly higher in the low disturbance forest compared with the other forests $(P=0.014)$. Mean liana infestation per plot differed significantly with respect to all the forest pairs (Table 2; $P<0.001$ ).

The five most important species in the low disturbance forest, namely, Salacia elegans (66.77), Calycobolus heudelotii (53.52), Calycobolus africanus (25.77), Neuropeltis acuminata (23.24), and Dichapetalum heudelotii (17.76) accounted for $62.4 \%$ of the total IVI in the low disturbance forest (Table 1). The five most important species in the moderate disturbance forest, namely, C. africanus (39.77), Alafia barteri (31.24), Millettia leucantha (23.31), Landolphia hirsuta (18.40), and Adenia rumicifolia (16.04) constituted $42.9 \%$ of the total IVI in the moderate disturbance forest. On the part of the high disturbance forest, Landolphia dulcis var. barteri (39.00), Hippocratea africana (29.66), A. barteri (20.69), Acacia kamerunensis (17.86), and Combretum sp. (16.59) represented the five most important species, and together, they made up $41.3 \%$ of the total IVI in this forest type.

The first axis of the PCA explained $58.6 \%$ of the variation in liana species dominance, whereas the second axis 


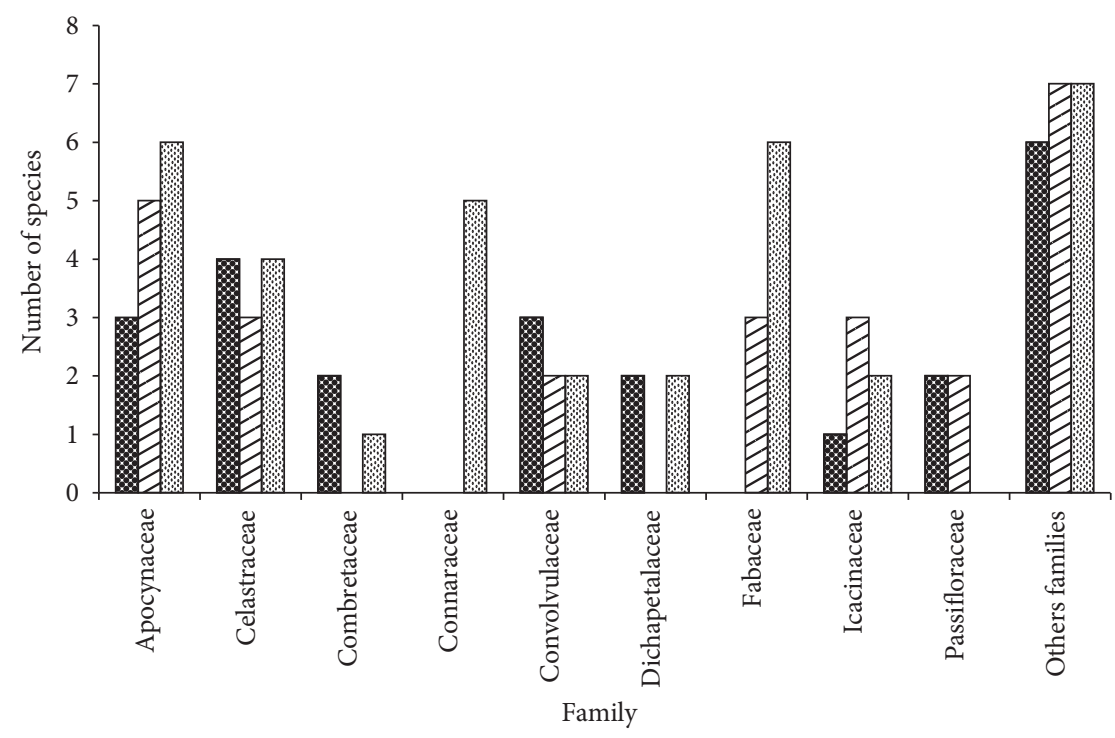

$\otimes \mathrm{LDF}$

$\checkmark \mathrm{MDF}$

가가

FIGURE 2: Liana species richness per family in the low (LDF), moderate (MDF), and high (HDF) disturbance forests.

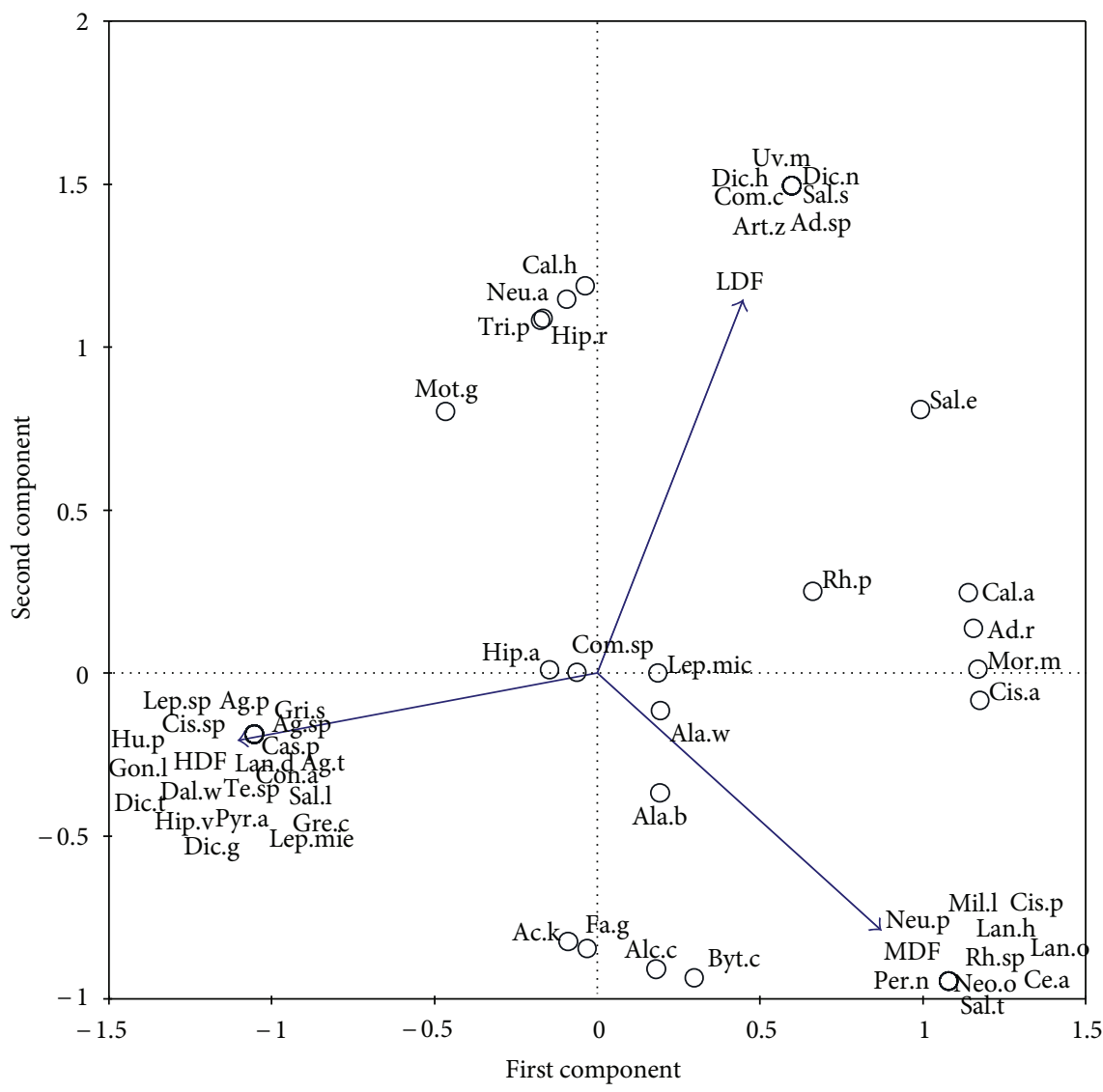

FIGURE 3: Projection of forest types and liana species in the PCA axes defined by the importance value index. The names of the species are coded with their initials. 


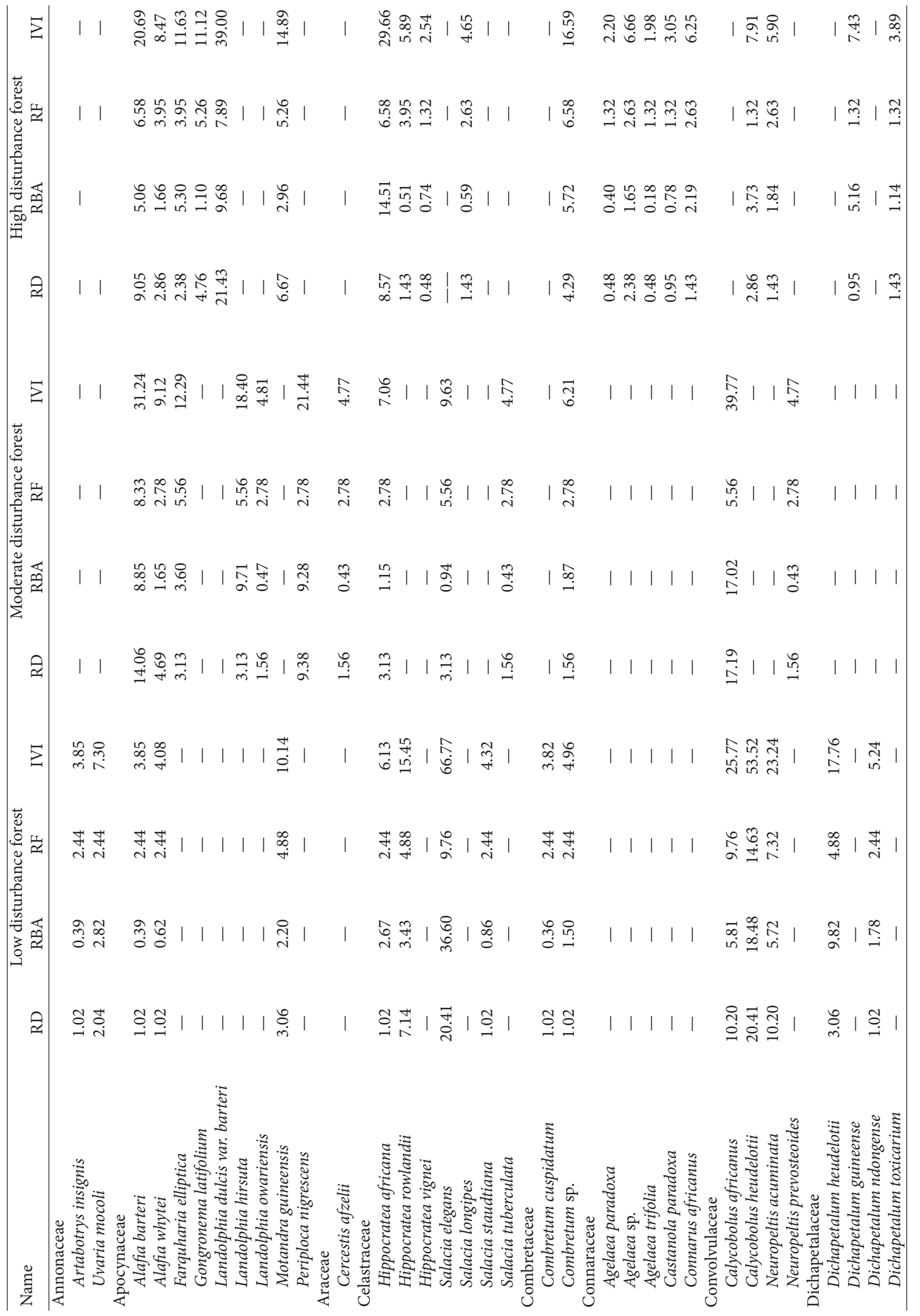




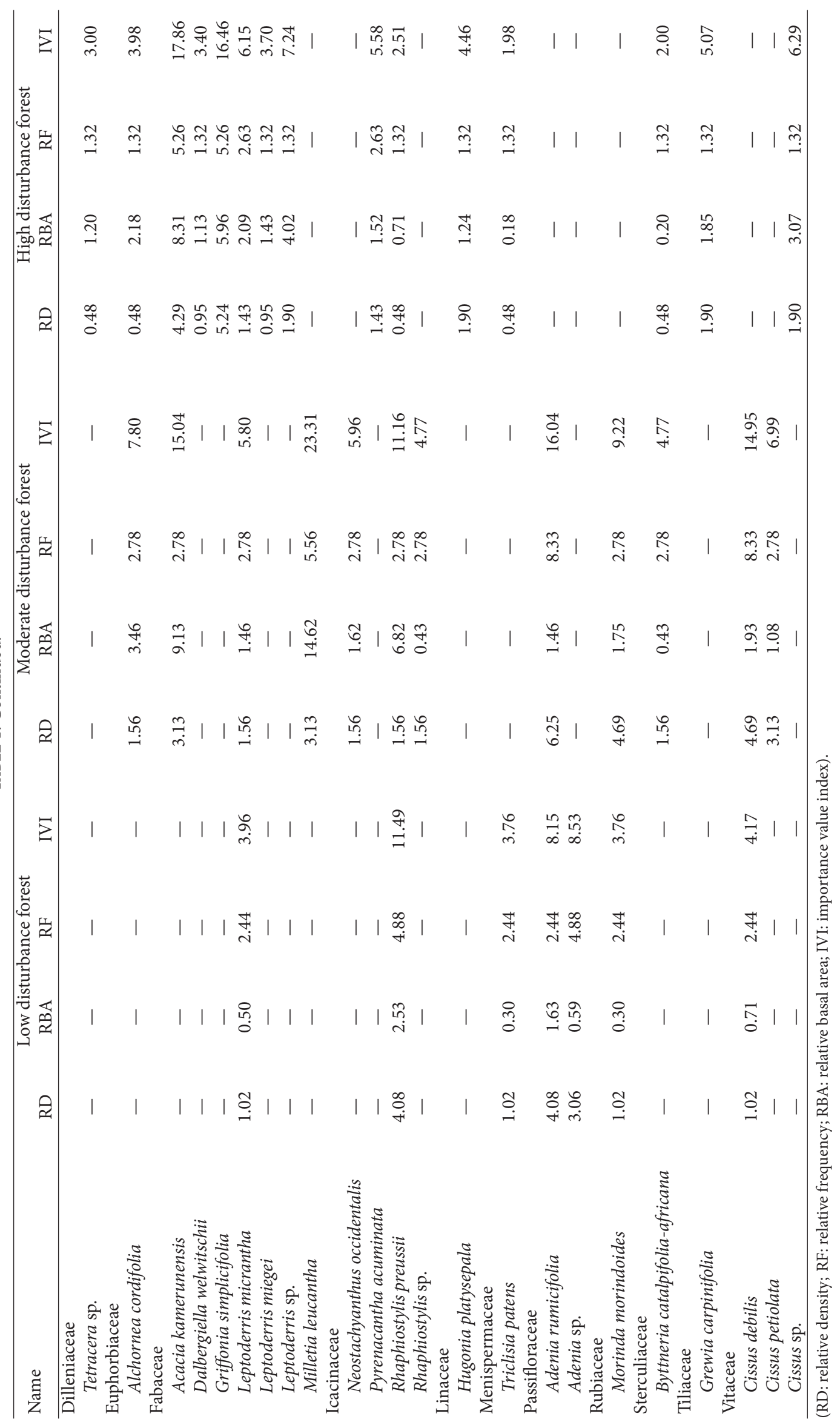


TABLE 2: Summary of liana characteristics in the low disturbance (LDF), moderate disturbance (MDF), and high disturbance (HDF) forests in the Southern Scarp Forest Reserve.

\begin{tabular}{|c|c|c|c|}
\hline \multirow{2}{*}{ Characteristic } & \multicolumn{3}{|c|}{ Forest type } \\
\hline & LDF & MDF & $\mathrm{HDF}$ \\
\hline Species richness/plot & $6.83^{\mathrm{a}} \pm 0.75$ & $6.33^{\mathrm{a}} \pm 0.76$ & $12.67^{b} \pm 0.72$ \\
\hline Number of individuals/forest type & 95 & 62 & 208 \\
\hline Abundance/plot & $15.8^{\mathrm{a}} \pm 1.12$ & $10.30^{\mathrm{a}} \pm 2.79$ & $34.70^{\mathrm{b}} \pm 1.36$ \\
\hline Mean liana dbh/plot & $3.2^{\mathrm{a}} \pm 0.26$ & $2.69^{\mathrm{a}} \pm 0.12$ & $3.0^{\mathrm{a}} \pm 0.21$ \\
\hline Mean basal area $\left(\mathrm{cm}^{2} / \mathrm{ha}\right) /$ plot & $239.12^{\mathrm{a}} \pm 17.60$ & $132.66^{\mathrm{b}} \pm 39.00$ & $153.66^{\mathrm{b}} \pm 10.70$ \\
\hline Mean liana infestation/plot (\%) & $48.80^{\mathrm{a}} \pm 4.87$ & $27.00^{\mathrm{b}} \pm 5.03$ & $70.70^{\mathrm{C}} \pm 6.84$ \\
\hline
\end{tabular}

Mean values within the same row that have different superscripts are significantly different $(P<0.05)$.

TABLE 3: Mean values of environmental variables in the low disturbance (LDF), moderate disturbance (MDF), and high disturbance (HDF) forests in the Southern Scarp Forest Reserve.

\begin{tabular}{|c|c|c|c|}
\hline \multirow{2}{*}{ Soil variable } & \multicolumn{3}{|c|}{ Forest type } \\
\hline & LDF & MDF & HDF \\
\hline Base saturation (\%) & $83.60^{\mathrm{a}} \pm 2.27$ & $84.10^{\mathrm{a}} \pm 3.24$ & $65.80^{\mathrm{b}} \pm 1.21$ \\
\hline Moisture (\%) & $26.74^{\mathrm{a}} \pm 0.50$ & $13.94^{\mathrm{b}} \pm 1.02$ & $16.95^{\mathrm{c}} \pm 0.60$ \\
\hline Organic matter (\%) & $7.05^{\mathrm{a}} \pm 0.48$ & $4.27^{\mathrm{b}} \pm 0.88$ & $3.10^{\mathrm{b}} \pm 0.49$ \\
\hline$N(\%)$ & $0.51^{\mathrm{a}} \pm 0.08$ & $0.33^{\mathrm{b}} \pm 0.04$ & $0.26^{\mathrm{b}} \pm 0.04$ \\
\hline TEB & $6.37^{\mathrm{a}} \pm 0.92$ & $6.18^{\mathrm{a}} \pm 1.04$ & $2.55^{\mathrm{b}} \pm 0.31$ \\
\hline $\operatorname{ECEC~(me/100~g)~}$ & $7.50^{\mathrm{a}} \pm 8.12$ & $7.15^{\mathrm{a}} \pm 0.98$ & $3.82^{\mathrm{b}} \pm 0.33$ \\
\hline Exch. acidity & $1.13^{\mathrm{ab}} \pm 0.06$ & $0.98^{\mathrm{a}} \pm 0.06$ & $1.27^{\mathrm{b}} \pm 0.12$ \\
\hline Exch. Ca (me/100 g) & $3.64^{a} \pm 0.62$ & $2.97^{\mathrm{ab}} \pm 0.60$ & $1.47^{\mathrm{b}} \pm 0.17$ \\
\hline Exch. K (me/100g) & $0.36^{\mathrm{a}} \pm 0.05$ & $0.39^{\mathrm{a}} \pm 0.04$ & $0.15^{\mathrm{b}} \pm 0.02$ \\
\hline Exch. $\mathrm{Mg}(\mathrm{me} / 100 \mathrm{~g})$ & $2.27^{\mathrm{a}} \pm 0.38$ & $2.74^{\mathrm{a}} \pm 0.90$ & $0.87^{\mathrm{b}} \pm 0.13$ \\
\hline Exch. Na (me/100 g) & $0.10^{\mathrm{a}} \pm 0.02$ & $0.09^{\mathrm{a}} \pm 0.01$ & $0.07^{\mathrm{a}} \pm 0.01$ \\
\hline Available K (ppm) & $105.50^{\mathrm{a}} \pm 8.76$ & $112.40^{\mathrm{a}} \pm 12.40$ & $67.20^{\mathrm{b}} \pm 9.88$ \\
\hline Available P (ppm) & $3.80^{\mathrm{a}} \pm 1.97$ & $13.70^{\mathrm{b}} \pm 2.44$ & $5.20^{\mathrm{a}} \pm 1.12$ \\
\hline $\mathrm{pH}$ & $4.4^{\mathrm{a}} \pm 0.06$ & $4.6^{\mathrm{a}} \pm 0.13$ & $4.2^{\mathrm{a}} \pm 0.14$ \\
\hline
\end{tabular}

Mean values within the same row that have different superscripts are significantly different $(P<0.05)$.

accounted for $37.8 \%$ of the variation. The first two axes clearly separated the three forest types based on the dominance of the species (Figure 3). Additionally, most of the species were separated into three distinct liana communities based on their dominance values (IVI), with each community in a particular forest. For instance, Leptoderris sp., Leptoderris miegei, Agelaea petiolata, Griffonia simplicifolia, and Dalbergiella welwitschii formed part of the liana group in the high disturbance forest. Species such as Millettia latifolia, Cissus petiolata, L. hirsuta, Cercestis afzelii, and Neuropeltis prevosteoides formed part of the liana cluster in the moderate disturbance forest. In the low disturbance forest, species such as Artabotrys insignis, Adenia sp., Salacia staudtiana, Combretum cuspidatum, and Uvaria mocoli formed part of the liana cluster. The PCA revealed another group of species which occurred in between the main liana clusters of forest pairs. These were species that showed high dominance in two forest pairs. For example, Motandra guineensis was found between liana clusters in the low and high disturbance forests because it had high dominance in these forests. Farquharia elliptica and Acacia kamerunenesis showed high dominance in the moderate and high disturbance forests and hence were located in between the liana clusters of these forests. Finally,
Rhaphiostylis sp., C. africanus, and A. rumicifolia recorded high dominance in the moderate and low disturbance forests and were therefore located between the liana groups found in these forest types. Species which occurred in all of the three forests with high IVI in at least one of the forests where distributed close to the center of the PCA diagram.

3.2. Factors Affecting Liana Species Richness and Structure. There were significant relationships between most liana species richness and structural parameters, and forest structural characteristics: tree density versus liana species richness $\left(P=0.019 ; r^{2}=0.253\right)$, tree abundance versus liana abundance $\left(P=0.018 ; r^{2}=0.26\right)$, tree $\mathrm{dbh}$ versus liana basal area $\left(P=0.032 ; r^{2}=0.11\right)$, and tree dbh versus liana $\mathrm{dbh}$ $\left(P=0.002 ; r^{2}=0.31\right)$. However, canopy cover did not serve as a significant predictor of liana species richness and abundance in the study $(P=0.096)$.

Most of the soil physicochemical factors differed significantly among the forest types, decreasing with increasing disturbance intensity (Table 3 ). Various relationships were expressed in the stepwise multiple regression analysis performed between liana species richness and structure, and soil properties (Table 4). Five of the soil variables had significant 
TABLE 4: Multiple regression (stepwise) analysis of the effects of environmental variables on liana species richness and structure (abundance, dbh, and basal area) in the Southern Scarp Forest Reserve. The final model included only those variables which made significant influence on the dependent variables.

\begin{tabular}{lclc}
\hline $\begin{array}{l}\text { Dependent } \\
\text { variable }\end{array}$ & $\begin{array}{c}r^{2} \\
\text { (adjusted) }\end{array}$ & Independent variable & $P$ value \\
\hline $\begin{array}{l}\text { Liana species } \\
\text { richness }\end{array}$ & 56.31 & Exchangeable magnesium & 0.041 \\
& & Exchangeable calcium & 0.022 \\
& & TEB & 0.019 \\
Liana & \multirow{2}{*}{68.27} & Exchangeable calcium & 0.000 \\
abundance & & TEB & 0.000 \\
& & Exchangeable sodium & 0.044 \\
& & pH & 0.044 \\
Liana DBH & 66.67 & Exchangeable magnesium & 0.021 \\
& & Exchangeable potassium & 0.022 \\
& & pH & 0.011 \\
Basal area & 76.23 & Exchangeable magnesium & 0.042 \\
& & Exchangeable sodium & 0.006 \\
\hline
\end{tabular}

influence on liana species richness and structure in the study $(P<0.05)$. Liana species richness and abundance significantly depended on exchangeable magnesium, exchangeable calcium, and TEB. In addition, liana abundance significantly depended on exchangeable sodium. Liana dbh and basal area were significantly influenced by exchangeable magnesium and $\mathrm{pH}$. Furthermore, liana dbh and basal area had significant relationships with exchangeable potassium and exchangeable sodium, respectively. Liana infestation related significantly with some of the soil parameters, namely, $\mathrm{pH}(P=0.042$; $r=-0.484)$, exchangeable acidity $(P=0.046 ; r=$ $0.475), \%$ base saturation $(P=0.037 ; r=-0.494)$, available phosphorus $(P=0.040 ; r=-0.489)$, and available potassium ( $P=0.008 ; r=-0.606)$. There was, however, no significant relationship between liana infestation and the rest of the environmental factors as well as forest structural characteristics (Table 5).

\section{Discussion}

The Southern Scarp Forest Reserve exhibited a higher species richness ( 56 species $\approx 62$ species/ha) in relation to other forest reserves in Ghana. For instance, in the Bobiri Forest Reserve, Ghana, a total of 27 species $(\approx 18$ species/ha) was recorded [17] whereas a much lower species richness $(27$ species $\approx 9$ species/ha) was reported in the Tinte Bepo Forest Reserve, Ghana [15]. Moreover, liana species richness in this study was higher than those reported from outside Ghana: 51 species/ha in Bolivia [28] and 44 species/ha in China [29]. A similar trend was observed with regard to liana abundance. In the present study, liana density of 406 individuals/ha obtained was higher than what was reported in the Tinte Bepo and
TABLE 5: Relationships between liana infestation and soil and forest structural characteristics in the Southern Scarp Forest Reserve. Pearson's correlation coefficient $(r)$ and $P$ values are provided.

\begin{tabular}{lcc}
\hline \multirow{2}{*}{ Factors } & \multicolumn{2}{c}{ Liana infestation } \\
& $r$ & $P$ \\
\hline Base saturation (\%) & -0.494 & $0.037^{*}$ \\
Moisture (\%) & -0.203 & 0.419 \\
Organic matter (\%) & -0.051 & 0.840 \\
$N$ (\%) & -0.087 & 0.730 \\
TEB & -0.350 & 0.154 \\
ECEC (me/100 g) & -0.322 & 0.192 \\
Exchangeable acidity & 0.475 & $0.046^{*}$ \\
Exchangeable Ca (me/100 g) & -0.253 & 0.312 \\
Exchangeable K (me/100 g) & -0.3785 & 0.121 \\
Exchangeable Mg (me/100 g) & -0.301 & 0.226 \\
Exchangeable Na (me/100 g) & -0.066 & 0.794 \\
Available K (ppm) & -0.606 & $0.008^{*}$ \\
Available P & -0.489 & $0.040^{*}$ \\
pH & -0.484 & $0.042^{*}$ \\
Tree abundance & 0.180 & 0.474 \\
Tree basal area & -0.130 & 0.608 \\
Canopy cover & 0.302 & 0.222 \\
\hline
\end{tabular}

${ }^{*}$ Significant relationship at a significance level of $5 \%$.

Bobiri forest reserves (253 individuals/ha and 213 individuals/ha, resp.) $[15,17]$. In the Democratic Republic of Congo, liana densities of 54 and 239 individuals/ha were recorded in a monodominant and mixed stands, respectively, in Ituri Forest [30]. Nevertheless, liana density in this study did not compare favourably with the results from other tropical forests: 531 individuals/ha [31] and 3569 individuals/ha [32].

The effect of disturbance on liana species richness and abundance was apparent in the current study. Generally, the high disturbance forest had significantly higher liana species richness and abundance, confirming the widely held finding that disturbance promotes liana success [33-36]. This pattern has been attributed to the ability of more disturbance forests to provide more favourable conditions for lianas than low disturbance forests [37-39]. Apocynaceae and Celastraceae maintained high species richness in all the forests indicating the ability of their species to thrive in forests with varied disturbance intensities.

The forest structural characteristics expressed mixed relationships with liana species richness and structure in the study. Tree abundance significantly predicted liana abundance in the study. This finding provides support for other studies which reported of significant dependence of liana abundance on abundance of trees $[15,40]$. The absence of significant relationship between liana abundance and canopy cover may be related to the ability of liana species in the forest to regenerate and grow well in shade and canopy gaps [39], leading to no clear cut pattern. Generally, the average level of liana infestation (48.8\%) recorded in the Southern Scarp Forest Reserve was lower than what has been reported in other forests $[2,17]$. The level of liana infestation 
increased significantly with disturbance intensity, showing that high levels of disturbance could be more favourable to liana colonisation. These findings indicate that different disturbance intensities could create differences in structure of forests, which could in turn, predict liana species richness and structure.

The patterns of dominance expressed by liana species indicated that liana communities in the three forests were distinct from one another. Unique species constituted the five most dominant species in each forest type with the exception of $C$. africanus which occurred in both the low and moderate disturbance forests. Furthermore, liana species were clustered into three different groups, one in each forest type. These patterns clearly demonstrated that liana species dominance responded differently to different disturbance intensities in the study area [17]. The equitability of distribution of IVI among liana species increased with disturbance intensity. For instance, the first ten species in the low disturbance forest accounted for $80 \%$ of the IVI of the species, whereas the first ten species in the moderate and high disturbance forests accounted for $67.9 \%$ and $62.1 \%$ of the IVI of the species, respectively. Disturbance therefore appeared to have reduced dominance of some species in the forests. This has the ability to enhance diversity of liana species in the forest reserve.

The findings of the current study have brought to the fore the important role soil properties can play in determining liana species richness and structure following human disturbance. Hitherto soil properties had been considered to be of less importance in determining liana species diversity and structure in some studies $[2,41-43]$. Soil pH and magnesium significantly affected liana species richness and structure in this study, providing support for a previous study [44] which had a similar result. Soil $\mathrm{pH}$ and magnesium have been found to influence ecological amplitudes of lianas [45]. In the light of this, it is possible that soil $\mathrm{pH}$ and magnesium affected liana species richness and structure by influencing the ecological amplitude of liana species (cf. [44]). Soil pH affects the availability of nutrients to plants by influencing nutrient solubility, microbial activity, and soil physical properties (cf. [44]). Low soil pH values were recorded in this study, and at such levels, nutrients availability becomes limited [46]. Thus, the influence of soil $\mathrm{pH}$ on liana species richness and structure might have occurred through its regulation of nutrients available to lianas in the forest reserve [44]. Generally, soil exchangeable cations exerted a greater influence on liana species richness and structure in the study compared to the other soil properties. Possibly, soil exchangeable cations influenced liana assemblage by controlling vital processes in lianas such as stomatal movement regulation, maintenance of plant turgor, phloem transport, protein synthesis, chlorophyll synthesis, and the activation of many enzymes, all of which are involved in growth and development of plants [47]. Whereas forest structure did not affect liana infestation significantly, some of the soil properties related significantly with liana infestation, confirming the hypothesis of Homeier et al. [2] that soil properties could be more decisive in liana infestation rate. Soil properties might have affected liana infestation by causing variation in liana abundance within the plots. In general, there were significant variations in soil physicochemical factors among the forest types which reflect the effects of human disturbance on soil fertility. In essence, human disturbance contributed to differences in soil physicochemical factors in the forests which in turn, influenced liana species richness and structure. Thus, apart from the direct effects of human disturbance on liana species richness and structure, it also had indirect influence on liana success through soil properties.

In conclusion, human disturbance had significant influence on liana species richness and structure in the forest types. Most of the soil physicochemical factors varied significantly among the forest types and related significantly with liana species richness and structure. In addition, liana species richness and structure depended significantly on some forest structural attributes. Human disturbance resulted in distinct liana communities within the forests on the basis of IVI of the species. The study revealed that following human disturbance, liana species richness and structure may alter as a result of changes in forest structure and soil properties caused by the disturbance.

\section{References}

[1] J. J. Gerwing, "Life history diversity among six species of canopy lianas in an old-growth forest of the eastern Brazilian Amazon," Forest Ecology and Management, vol. 190, no. 1, pp. 57-72, 2004.

[2] J. Homeier, F. Englert, C. Leuschner, P. Weigelt, and M. Unger, "Factors controlling the abundance of lianas along an altitudinal transect of tropical forests in Ecuador," Forest Ecology and Management, vol. 259, no. 8, pp. 1399-1405, 2010.

[3] S. A. Schnitzer and F. Bongers, "The ecology of lianas and their role in forests," Trends in Ecology and Evolution, vol. 17, no. 5, pp. 223-230, 2002.

[4] S. A. Schnitzer, M. P. E. Parren, and F. Bongers, "Recruitment of lianas into logging gaps and the effects of pre-harvest climber cutting in a lowland forest in Cameroon," Forest Ecology and Management, vol. 190, no. 1, pp. 87-98, 2004.

[5] D. R. Pérez-Salicrup, "Effect of liana cutting on tree regeneration in a liana forest in Amazonian Bolivia," Ecology, vol. 82, no. 2, pp. 389-396, 2001.

[6] D. R. Pérez-Salicrup and M. G. Barker, "Effect of liana cutting on water potential and growth of adult Senna multijuga (Caesalpinioideae) trees in a Bolivian tropical forest," Oecologia, vol. 124, no. 4, pp. 469-475, 2000.

[7] S. A. Schnitzer, J. W. Dalling, and W. P. Carson, "The impact of lianas on tree regeneration in tropical forest canopy gaps: evidence for an alternative pathway of gap-phase regeneration," Journal of Ecology, vol. 88, no. 4, pp. 655-666, 2000.

[8] Z. Q. Cai, S. A. Schnitzer, and F. Bongers, "Seasonal differences in leaf-level physiology give lianas a competitive advantage over trees in a tropical seasonal forest," Oecologia, vol. 161, no. 1, pp. 25-33, 2009.

[9] J. R. Foster, P. A. Townsend, and C. E. Zganjar, "Spatial and temporal patterns of gap dominance by low-canopy lianas detected using EO-1 Hyperion and Landsat Thematic Mapper," Remote Sensing of Environment, vol. 112, no. 5, pp. 2104-2117, 2008.

[10] L. L. Ingwell, S. Joseph Wright, K. K. Becklund, S. P. Hubbell, and S. A. Schnitzer, "The impact of lianas on 10 years of 
tree growth and mortality on Barro Colorado Island, Panama," Journal of Ecology, vol. 98, no. 4, pp. 879-887, 2010.

[11] S. E. Rutishauser, Increasing liana abundance and biomass in tropical forests: testing mechanistic explanations [M.S. thesis], University of Wisconsin, Milwaukee, Wis, USA, 2011.

[12] M. D. Swaine and J. Grace, "Lianas may be favoured by low rainfall: evidence from Ghana," Plant Ecology, vol. 192, no. 2, pp. 271-276, 2007.

[13] S. D. Zhu and K. F. Cao, "Hydraulic properties and photosynthetic rates in co-occurring lianas and trees in a seasonal tropical rainforest in Southwestern China," Plant Ecology, vol. 204, no. 2, pp. 295-304, 2009.

[14] G. Zotz, N. Cueni, and C. Körner, "In situ growth stimulation of a temperate zone liana (Hedera helix) in elevated $\mathrm{CO}_{2}$," Functional Ecology, vol. 20, no. 5, pp. 763-769, 2006.

[15] P. Addo-Fordjour, A. K. Anning, J. A. Larbi, and S. Akyeampong, "Liana species richness, abundance and relationship with trees in the Bobiri forest reserve, Ghana: impact of management systems," Forest Ecology and Management, vol. 257, no. 8, pp. 1822-1828, 2009.

[16] P. Addo-Fordjour, S. Obeng, M. G. Addo, and S. Akyeampong, "Effects of human disturbances and plant invasion on liana community structure and relationship with trees in the Tinte Bepo forest reserve, Ghana," Forest Ecology and Management, vol. 258, no. 5, pp. 728-734, 2009.

[17] P. Addo-Fordjour, Z. B. Rahmad, and A. M. S. Shahrul, "Effects of human disturbance on liana community diversity and structure in a tropical rainforest, Malaysia: implication for conservation," Journal of Plant Ecology, vol. 5, no. 4, pp. 391-399, 2012.

[18] S. A. Schnitzer, "A mechanistic explanation for global patterns of liana abundance and distribution," American Naturalist, vol. 166, no. 2, pp. 262-276, 2005.

[19] F. Bongers, L. Poorter, W. D. Hawthorne, and D. Sheil, "The intermediate disturbance hypothesis applies to tropical forests, but disturbance contributes little to tree diversity," Ecology Letters, vol. 12, no. 8, pp. 798-805, 2009.

[20] W. D. Hawthorne, Ecological Profiles of Ghanaian Forest Trees, Tropical Forestry Paper 29, Oxford Forestry Institute, Oxford, UK, 1995.

[21] W. D. Hawthorne, "Holes and the sums of parts in Ghanaian forest: regeneration, scale and sustainable use," Proceedings of the Royal Society of Edinburgh Section B, vol. 104, pp. 75-176, 1996.

[22] W. D. Hawthorne and M. Abu Juam, Forest Protection in Ghana (with Particular Reference to Vegetation and Plant Species), IUCN, Gland, Switzerland, 1995.

[23] M. Arbonnier, Trees, Shrubs and Lianas of West African Dry Zones, CIRAD, MARGRAF Publishers, 2004.

[24] W. D. Hawthorne and C. Jongkind, Woody Plants of Western African Forests: A Guide to the Forest Trees, Shrubs and lianes From Senegal to Ghana, Royal Botanic Gardens, Kew, UK, 2006.

[25] W. D. Hawthorne, Field Guide to the Forest Trees of Ghana, Ghana Forestry Series 1, Natural Resources Institute, for the Overseas Development Aministration, London, UK, 1990.

[26] L. Poorter, F. Bongers, F. N. Kouamé, and W. D. Hawthorne, Eds., Biodiversity of West African Forests: An Ecological Atlas of Woody plant Species, CABI, 2004.

[27] Soil Survey Staff, "Soil survey laboratory methods manual," Soil Survey Investigations. Report no. 42, U.S. Government Printing Office, Washington, DC, USA, 1996.
[28] D. R. Pérez-Salicrup, V. L. Sork, and F. E. Putz, "Lianas and trees in a liana forest of amazonian Bolivia," Biotropica, vol. 33, no. 1, pp. 34-47, 2001.

[29] X. T. Lü, J. W. Tang, Z. L. Feng, and M. H. Li, "Diversity and aboveground biomass of lianas in the tropical seasonal rain forests of Xishuangbanna, SW China," Revista de Biologia Tropical, vol. 57, no. 1-2, pp. 211-222, 2009.

[30] J. R. Makana, T. B. Hart, and J. A. Hart, "Forest structure and diversity of lianas and understorey treelets in monodominant and mixed stands in the Ituri forest, Democratic republic of the Congo," in Forest Biodiversity Research, Monitoring and Modeling. Conceptual Background and Old World Case Studies, F. Dallmeier and J. A. Comiskey, Eds., pp. 429-446, Parthenon, Paris, France, 1998.

[31] M. P. E. Parren and F. Bongers, "Abundance and distribution of lianas in a highly disturbed forest tropical rain forest in southern Cameroon," in Lianas and Logging in West Africa, M. P. E. Parren, Ed., Tropenbos-Cameroon Series 6, pp. 67-80, Tropenbos International, Wageningen, The Netherlands, 2003.

[32] F. Senbeta, C. Schmitt, M. Denich et al., "The diversity and distribution of lianas in the Afromontane rain forests of Ethiopia," Diversity and Distributions, vol. 11, no. 5, pp. 443-452, 2005.

[33] F. Bongers, M. P. E. Parren, and M. D. Swaine D, "Forest climbing plants of West Africa: introduction," in Forest Climbing Plants of West Africa: Diversity, Ecology and Management, F. Bongers, M. P. E. Parren, and D. Traoré, Eds., pp. 5-18, CAB International, Wallingford, UK, 2005.

[34] G. Ibarra-Manríquez and M. Martínez-Ramos, "Landscape variation of liana communities in a Neotropical rain forest," Plant Ecology, vol. 160, no. 1, pp. 91-112, 2002.

[35] K. Kokou, P. Couteron, A. Martin, and G. Caballe, “Taxonomic diversity of lianas and vines in forest fragments of southern Togo," Revue d'Ecologie, vol. 57, no. 1, pp. 3-18, 2002.

[36] M. E. Kuzee and F. Bongers, "Climber abundance, diversity and colonization in degraded forests of different ages in Côte d'voire," in Forest Climbing Plants of West Africa: Diversity, Ecology and Management, F. Bongers, M. P. E. Parren, and D. Traoré, Eds., pp. 73-91, CAB International, Wallingford, UK, 2005.

[37] J. J. Gerwing and D. L. Farias, "Integrating liana abundance and forest stature into an estimate of total aboveground biomass for an eastern Amazonian forest," Journal of Tropical Ecology, vol. 16, no. 3, pp. 327-335, 2000.

[38] W. F. Laurance, D. Pérez-Salicrup, P. Delamônica et al., "Rain forest fragmentation and the structure of Amazonian liana communities," Ecology, vol. 82, no. 1, pp. 105-116, 2001.

[39] P. W. Richards, in The Tropical Rain Forest an Ecological Study, Cambridge University Press, Cambridge, UK, 1996.

[40] C. M. Yuan, W. Y. Liu, C. Q. Tang, and X. S. Li, "Species composition, diversity, and abundance of lianas in different secondary and primary forests in a subtropical mountainous area, SW China," Ecological Research, vol. 24, no. 6, pp. 1361-1370, 2009.

[41] S. J. DeWalt and J. Chave, "Structure and biomass of four lowland neotropical forests," Biotropica, vol. 36, no. 1, pp. 7-19, 2004.

[42] K. Lertpanich and W. Y. Brockelman, "Lianas and environmental factors in the Mo Singto biodiversity research plot, Khao Yai National Park, Thailand," The Natural History Journal of Chulalongkorn University, vol. 3, no. 2, pp. 7-17, 2003.

[43] O. L. Phillips, R. V. Martínez, A. M. Mendoza, T. R. Baker, and P. N. Vargas, "Large lianas as hyperdynamic elements of the 
tropical forest canopy," Ecology, vol. 86, no. 5, pp. 1250-1258, 2005.

[44] P. Addo-Fordjour and Z. B. Rahmad, "Shahrul. Environmental factors influencing liana community diversity, structure and habitat associations in a tropical hill forest, Malaysia," Plant Ecology and Diversity. In review.

[45] M. J. Macía, K. Ruokolainen, H. Tuomisto, J. Quisbert, and V. Cala, "Congruence between floristic patterns of trees and lianas in a southwest Amazonian rain forest," Ecography, vol. 30, no. 4, pp. 561-577, 2007.

[46] F. Bagamba, R. Ruben, and M. Rufino, "Determinants of banana productivity and technical efficiency in Uganda," Research Report of the International Food Policy Research Institute, no. 155, pp. 109-128, 2007.

[47] T. V. Karpinets and D. J. Greenwood, "Potassium dynamics," in Handbook of Processes and Modeling in the Soil-Plant System, D. K. Benbi and R. Nieder, Eds., Haworth Press, New York, NY, USA, 2003. 

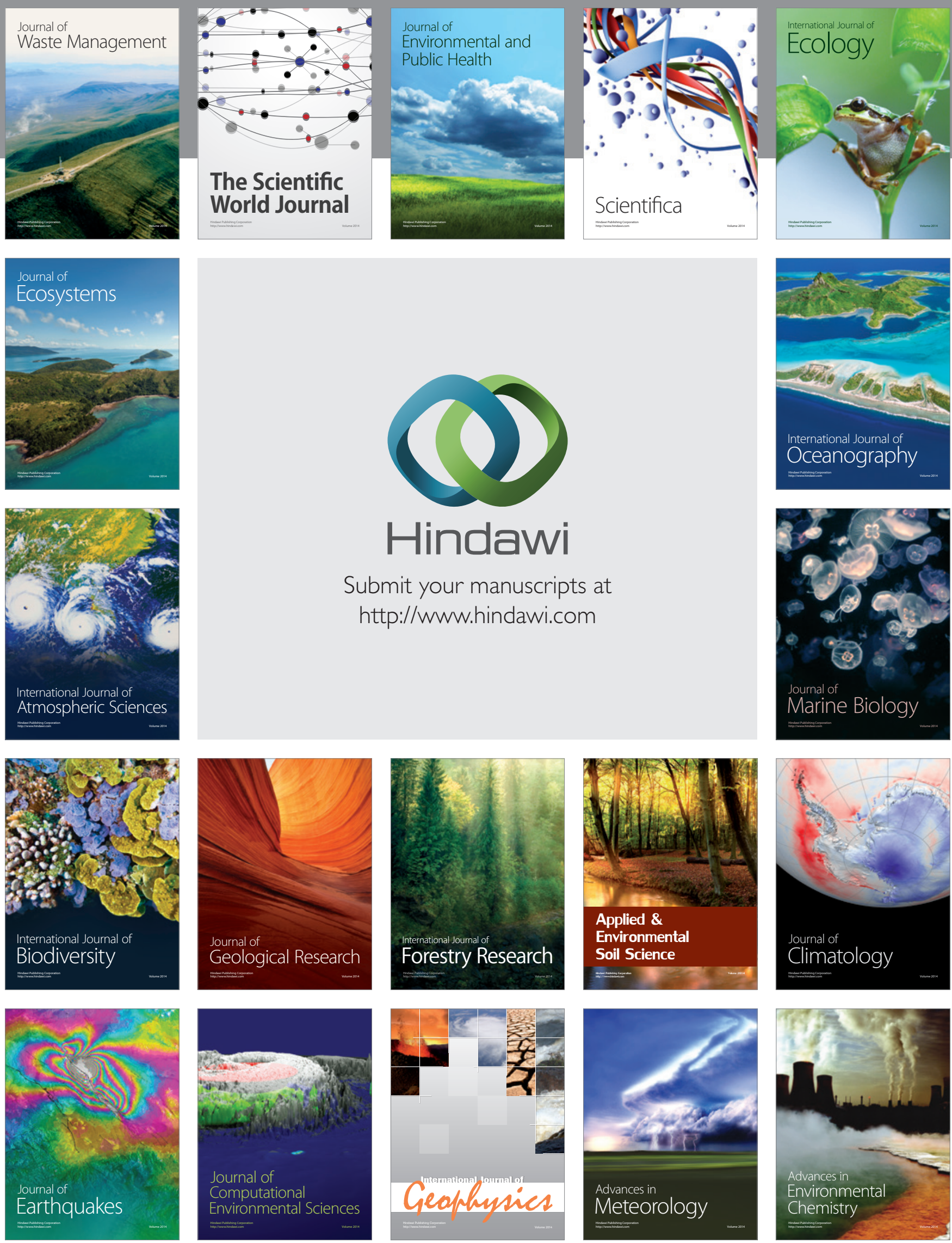